\title{
FARMACIJOS SPECIALISTŲ KONSULTACIJŲ TURINYS IŠDUODANT NERECEPTINIUS VAISTUS
}

\author{
Jurgita Daukšiene் ${ }^{1,2}$, Laimutė Jonaitiene், ${ }^{2}$ Edita Baboniené ${ }^{2}$ \\ ${ }^{1}$ Lietuvos sveikatos mokslu universiteto Medicinos akademijos Farmacijos fakultetas, \\ ${ }^{2}$ Kauno kolegijos Medicinos fakultetas
}

Raktažodžiai: farmacijos specialistai, farmacinè paslauga, konsultavimas, nereceptiniai vaistai.

\section{Santrauka}

Nereceptinių vaistinių preparatų vartojimas siejamas su savigyda, kuri tampa vis populiaresnè visuomenejje, tačiau neracionaliai vartojami vaistai gali padaryti daug žalos sveikatai. Farmacijos specialistų konsultacija ir suteikiama informacija, išduodant nereceptinius preparatus, gali užkirsti kelią neracionaliam vaistų vartojimui. Darbo tikslas - atskleisti farmacijos specialistų vaidmenį, išduodant nereceptinius vaistinius preparatus visuomenès vaistinejje. Pasirinktas struktūrizuoto stebẻjimo tyrimas. Išanalizuotas daugiau kaip 4000 konsultacijų visuomenès vaistinèse turinys. Rezultatai: iš stebètų 4198 farmacijos specialistų konsultacijų, 1738 atvejais gyventojų buvo įsigyjami nereceptiniai vaistai. Pagrindiniai sveikatos nusiskundimai buvo: peršalimas $(16,1$ proc.), odos problemos (13,2 proc.), skausmas (25,6 proc.), bendrai savijautai gerinti 28,7 (28,7 proc.), virškinimo sutrikimas (16,2 proc.). Gyventojai dažniausiai buvo informuojami apie vaisto vartojimo būdą (79,6 proc.), vartojimo laiką (67,1 proc.), vartojimo trukmę (36,3 proc.), apie galimas kontraindikacijas ar vaisto nepageidaujamą poveikị (11 proc.), sąveikas (6 proc.). Farmacijos specialistų informacijos suteikimo būdai: žodžiu (63,5 proc.), žodžiu ir raštu (22 proc.), tik raštu (1,5 proc), informacija nebuvo suteikta ( 13 proc.). Išvados: gyventojai kreipiasi ị visuomenes vaistines įvairiems negalavimams ir ju simptomams šalinti skirtų nereceptinių preparatų. Farmacijos specialistai suteikia konsultaciją nereceptinius vaistus icsigyjantiems pacientas ir konsultuoja juos apie racionalu vaistu vartojimą, nors ne visi informaciniai aspektai yra aptariami vienodai demesin- gai. Dažniausiai žodžiu informuoja, kaip reikia vartoti vaistą, bet rečiau aptaria galimas sąveikas, kontraindikacijas ar nepageidaujamus poveikius.

\section{Ivadas}

Lietuvos Respublikos farmacijos įstatyme farmacinè paslauga apibrèžiama kaip vaistininko praktika vaistinejje, apimanti gydytojo išrašytų receptų kontrolę, vertinimą, nereceptinių vaistinių preparatų parinkimą, farmacinès informacijos apie vaistinius preparatus teikimą gyventojams, sveikatos priežiūros ir farmacijos specialistams, taip pat jų konsultavimą [1]. Farmacinès paslaugos kokybę reglamentuoja „Geros vaistinès praktikos nuostatai“, kuriais remdamasis vaistininkas vykdo reikalavimus, padedančius išsaugoti vaisto kokybę ir tinkamai aptarnauti pacientą [2, 3]. Kita vertus, šiuo metu pereinama nuo produkto kokybès užtikrinimo prie veiklos, orientuotos ị pacientą $[4,5]$. İsigydamas vaistų pacientas sužino, kaip vartoti vaistą, apie vaisto teikiamą naudą, pavojus. Farmacijos specialistas, parduodamas vaistus gyventojui vaistineje, atlieka globejo, vadybininko, sprendimų prièmèjo, besimokančio visą gyvenimą, konsultanto vaidmenis [5]. İvairiose šalyse atlikti tyrimai liudija, jog vaistininkai - lengviausiai pasiekiami sveikatos priežiūros specialistai [ 6]. Jie yra vaistų ekspertai, galintys pakonsultuoti ne tik pacientus, bet ir kitus sveikatos priežiūros specialistus. Vis populiarejant savigydai bei didejjant be recepto parduodamų vaistų kiekiui [7, 8], farmacijos specialistas dažnai yra vienintelis sveikatos priežiūros specialistas, su kuriuo konsultuojasi nereceptinius vaistus ịsigyjantis pacientas. Savigydos pramonès asociacija išskiria 5 populiariausias savigydos sritis: bendrai savijautai gerinti, skausmui malšinti, peršalimo simptomams šalinti, virškinimo ir odos problemoms spręsti [9]. Nereceptiniai vaistiniai preparatai gali būti naudingi gyventojo sveikatai arba sukelti žalą, todèl farmacijos specialistai atlieka svarbu vaidmeni bendraujant su gyventoju ir užtikrinant saugu nereceptiniu 
vaistinių preparatų vartojimą [3,9]. Savigyda ir racionalus nereceptinių vaistinių preparatų vartojimas turi teigiamų savybių. Šiuo gydymosi būdu yra mažinamos sveikatos priežiūros išlaidos ir vizitų skaičius pas gydytojus, didinamas sveikatos priežiūros prieinamumas nuošalių vietų gyventojams [7]. Kita vertus, netinkamas nereceptinių vaistinių preparatų vartojimas gali padaryti daugiau žalos negu naudos. Nors informacijos nauda sèkmingam vaistų vartojimui yra plačiai išnagrinèta [5], bet pasitaiko atvejų, kai pacientams nesuteikiama ar dalinai suteikiama konsultacija $[10,11]$. Pabrèžtina, kad kiekviena konsultacija yra individuali farmacijos specialisto ir atskiro paciento sąveika, kurios metu svarbūs įvairūs vidiniai ir išoriniai veiksmai [12-15].

1 lentelè. Sociodemografiniai stebimujų duomenys $(\mathrm{N}=4198)$

\begin{tabular}{|l|l|l|l|l|l|}
\hline \multicolumn{2}{|l|}{$\begin{array}{l}\text { Tiriamujų demo- } \\
\text { grafiniai duome- } \\
\text { nys }\end{array}$} & \multicolumn{2}{l|}{ Stebimieji } & \multicolumn{2}{l|}{$\begin{array}{l}\text { Stebimieji, isigiję tik } \\
\text { nereceptini vaistą }\end{array}$} \\
\cline { 3 - 7 } & & $\begin{array}{l}\text { S k a i - } \\
\text { čius (N) }\end{array}$ & $\begin{array}{l}\text { Procentai } \\
\text { (proc.) }\end{array}$ & $\begin{array}{l}\text { Skaičius } \\
\text { (N) }\end{array}$ & $\begin{array}{l}\text { Procentai } \\
\text { (proc.) }\end{array}$ \\
\hline \multirow{2}{*}{ Lytis } & Moteris & 2754 & 65,6 & 1132 & 65,2 \\
\cline { 2 - 6 } & Vyras & 1443 & 34,4 & 606 & 34,8 \\
\hline Iš viso & $\mathbf{4 1 9 8}$ & $\mathbf{1 0 0}$ & $\mathbf{1 7 3 8}$ & $\mathbf{1 0 0}$ \\
\hline \multirow{3}{*}{ Amžius } & $18-30$ & 927 & 22,1 & 437 & 25,1 \\
\cline { 2 - 6 } & $30-55$ & 1849 & 44,0 & 802 & 46,1 \\
\cline { 2 - 6 } & $55<$ & 1401 & 43,0 & 488 & 28,1 \\
\hline Iš viso & $\mathbf{4 1 9 8}$ & $\mathbf{1 0 0}$ & $\mathbf{1 7 3 8}$ & $\mathbf{1 0 0}$ \\
\hline
\end{tabular}

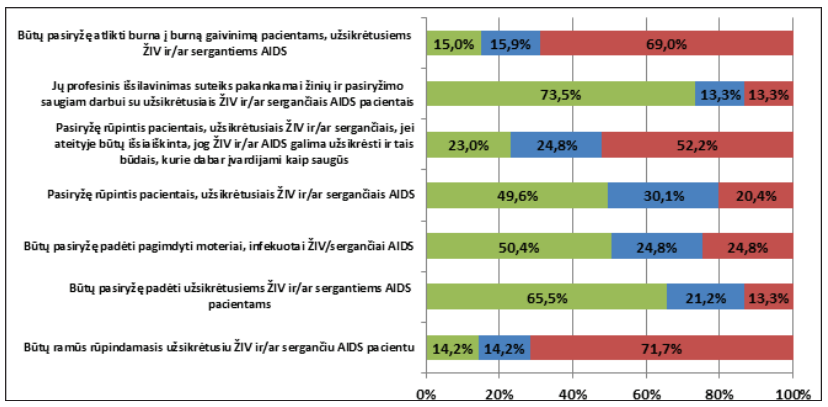

1 pav. Pacientų įsigyjami vaistiniai preparatai ir vaistinių prekès vaistinèje $(\mathrm{N}-4198)$

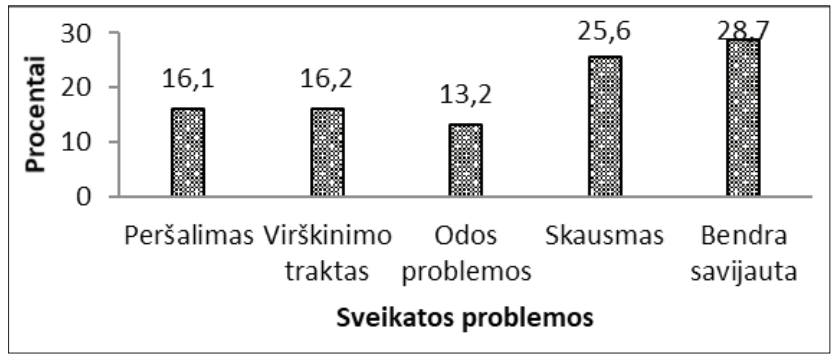

2 pav. Sveikatos sutrikimai pacientų, i̦sigyjančių vaistinius preparatus ir vaistinių prekes vaistineje $(\mathrm{N}-1739)$
Tyrimo tikslas - ịvertinti farmacijos specialistų konsultacijų turinị išduodant nereceptinius vaistinius preparatus visuomenès vaistinèje.

\section{Tyrimo objektas ir metodas}

Tyrimo objektas - farmacijos specialistų konsultacijos turinys, išduodant nereceptinius vaistus.

Atliekant tyrimą, taikyti metodai: mokslo šaltinių analizè, stuktūrizuoto stebejimo metodas. Tyrimo metu 26 Lietuvos

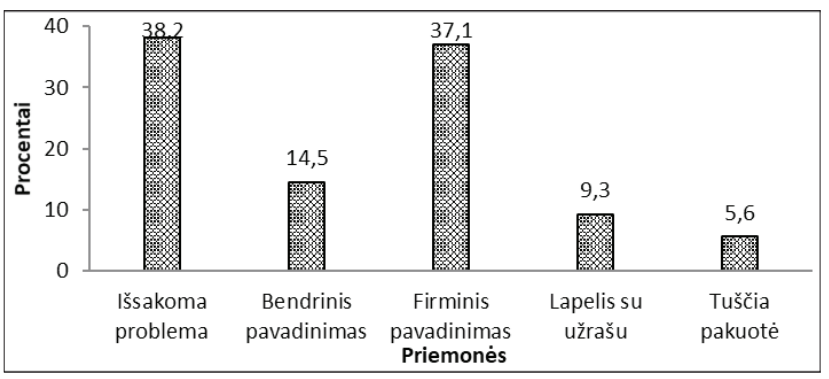

3 pav. Pacientų naudojamos priemonès, padedančios vaistinėje ịsigyti vaistinius preparatus, vaistinių prekes $(\mathrm{N}-1739)$

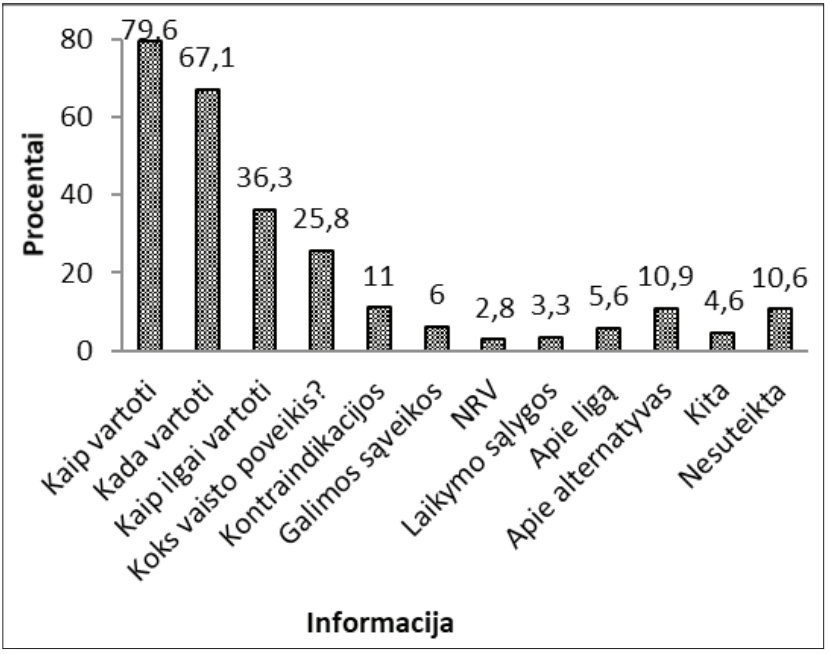

4 pav. Vaistinejje farmacijos specialisto suteikiama pacientui farmacinè informacija $(\mathrm{N}-1739)$

\begin{tabular}{|c|c|c|c|c|c|}
\hline \multirow{3}{*}{ 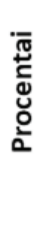 } & \multirow[t]{3}{*}{$\begin{array}{r}100 \\
50 \\
0\end{array}$} & $\begin{array}{l}13 \\
\sqrt{13}\end{array}$ & $\begin{array}{l}22 \\
\text { 畄 }\end{array}$ & 1,5 & 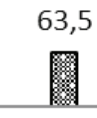 \\
\hline & & Nesuteikè & $\begin{array}{c}\text { Žodžiu ir } \\
\text { raštu }\end{array}$ & Raštu & Žodžiu \\
\hline & & \multicolumn{4}{|c|}{ Informacijos suteikimo būdas } \\
\hline
\end{tabular}

5 pav. Vaistinėje farmacijos specialisto suteikiamos pacientui farmacinès informacijos pateikimo būdai $(\mathrm{N}-1739)$ 
vaistinèse, gavus tuo metu dirbusių farmacijos specialistų (iš viso stebètas 34 specialistų darbas) leidimą, buvo stebimos jų teikiamos konsultacijos, išduodant vaistinius preparatus, vaistinių prekes. Statistinè duomenų analizė atlikta naudojant SPSS 17.0 ir Microsoft Office programinę įrangą. Tyrimas buvo atliekamas nuo $2016 \mathrm{~m}$. gegužès 24 dienos iki 2016 m. liepos 06 dienos.

Tyrimui atlikti buvo pasirinktas stebejjimo metodas, kuris padeda tyrèjui surinkti duomenis apie individualų asmenų elgesi ir veiklas tyrimo lauke (Creswell, 2009). Remiantis Kardelio (2016) stebejjimo metodo aprašymais, galima teigti, kad šis stebejjimo tyrimas nepriklausè nuo tiriamojo nuostatų, noro atsakinèti ì pateiktus klausimus. Tiriamojo veiksmus ir elgesi galima tiksliau ịvertinti jị stebint, nei apklausiant pati tiriamajị. Stebejjimo metu fiksuojamos tiriamųjų elgesio kategorijų duomenys buvo žymimi stebėjimo lentelèse. Iš viso buvo užpildyta 4198 stebėjimo lentelių, iš kurių atrinkti 1738 atvejai, kai buvo pirkti nereceptiniai vaistiniai preparatai ir kitos vaistinių prekès.

Stebejjimo lentelių kategorijos skirstytos ị šias dalis:

1) demografiniai duomenys,

2) paciento apsilankymo vaistinèje priežastys,

3) paciento nusiskundimai ir poreikiai,

4) farmacijos specialisto suteiktos informacijos pacientui turinys,

5) farmacijos specialisto informacijos pacientui suteikimo būdai.

Tyrimo metu vaistinèse atsitiktinai stebėta 4198 vaistinių preparatų ar vaistinių prekių pirkimai, kurių metu farmacijos specialistas konsultavo pacientą. Analizuojant bendrus duomenis, pastebėta, kad didžiają pacientų dalị sudaré moterys (65,6proc.). Nereceptinius vaistinius preparatus arba kitą vaistinę prekę ịsigijo du kartus daugiau moterų negu vyrų. Analizuojant duomenis pagal amžių, pastebėta, kad vaistinèje daugiausia lankèsi vidutinio (44,0 proc.) arba vyresnio amžiaus gyventojai (43,0 proc.), o nereceptinius vaistinius preparatus arba kitą vaistinę prekę daugiausia pirko 30-55 metų asmenys $(46,1)$ (1 lentelè).

\section{Rezultatai ir jų aptarimas}

Vertinant tyrimo rezultatus, buvo pastebèta, kad pacientai dešimtadaliu daugiau ịsigijo nereceptinių vaistinių preparatų, negu receptinių. Kitos vaistinių prekès sudarè 14,5 proc. visų pardavimų. Retais atvejais vienu pirkimu pacientai pirko receptinius ir nereceptinius vaistinius preparatus (1. pav.).

Šiame darbe akcentuojamos farmacijos specialisto konsultacijos, kurios susijusios su nereceptinių vaistinių preparatų išdavimu, todèl tolimesnę rezultatų analizę susiejome su nereceptinių vaistų įsigijimu.

Tyrimas parodè, kad priežastys, lemiančios įsigyti ne- receptinius vaistinius preparatus, yra sveikatos sutrikimų problemos, kurios pasirode įvairios, nelabai galinčios išsiskirti ar ryškiai dominuoti tarp respondentų nurodytų negalavimų. Apie ketvirtadalis respondentų skundèsi prasta bendra savijauta ir skausmu. Daugiau kaip po dešimtadalị apklaustujų vargino peršalimo simptomai, virškinimo trakto, odos problemos (2 pav.).

Europos Sajungos farmacijos grupès [18] duomenimis, dažniausiai gyventojai nereceptiniais vaistiniais preparatais gydosi ir ị vaistinę ateina esant bendriems negalavimams. Airijoje atlikti tyrimai rodo, kad, esant virškinimo sutrikimui, peršalimui, gripui, spuogams, dėmėms ir bèrimams, gyventojai dažniau konsultuojasi su farmacijos specialistu, negu su gydytoju.

Pastebėta, kad dažnai nereceptiniais vaistiniais preparatais gydomasi, esant raumenų ir sąnarių skausmui, nubrozdinimams, ipjovimams, alergijai, viduriavimui $[11,18]$.

Maltoje atlikto mokslinio tyrimo metu nustatyta, kad gyventojai dažniausiai kreipiasi ị farmacijos specialistą. Nereceptiniais vaistiniais preparatais jie gydosi esant kosuliui, peršalimui, konstipacijai, viduriavimui ir aknei [19]. Tyrimo rezultatai parodè, kad daugiau kaip trečdalis respondentų pradèjo pokalbị su farmacijos specialistu, nurodydami savo sveikatos sutrikimo problemą (3 pav.). Pokalbis apie sveikatos sutrikimus turi intymumo atspalvị ir pasitarnauja farmacijos specialisto konsultacijos plètrai. Tyrimai rodo, kad farmacijos specialistai labiau linkę konsultuoti pacientus tuomet, kai pacientai išsako problemą ir prašo pakonsultuoti nei tuomet, kai pacientas ateina jau pasirinkęs preparatą $[12,15]$.

Trečdalis respondentų, bendraudami su farmacijos specialistu, prašè vaisto, pasakydami firminị vaistinio preparato pavadinimą, daugiau kaip dešimtadalis pasakè vaistinio preparato bendrini pavadinimą.

Dešimtadalyje atvejų buvo išsakoma problema ir parodomas lapelis su užrašu, keletu pavienių atvejų parodoma tuščia pakuotè (3 pav.).

Lietuvos Respublikos farmacijos įstatymas, gera vaistinių praktika ir kiti įstatymai nurodo, kokią informaciją apie vaistų vartojimą turi suteikti farmacijos specialistas. Šis tyrimas parodè, kokią informaciją suteikè farmacijos specialistai gyventojams, ìsigyjantiems nereceptinius vaistinius preparatus. Pastebėta, kad trys ketvirtadaliai pacientų buvo informuojami apie vaisto vartojimo būdą, mažiau kaip trys ketvirtadaliai - apie vaisto vartojimo laiką (4 pav.). Dešimtadalị pacientų farmacijos specialistai informavo apie galimus šalutinius vaisto poveikius, dešimtadalị pacientų - apie alternatyvius vaistus ar gydymosi būdus, ir retai konsultavo apie ligą, nepageidaujamas reakcijas ị vaistą (NRV), galimas vaistų sąveikas. Dešimtadaliui tiriamųjų nebuvo suteikta farmacinè konsultacija (4 pav.). 
Užsienyje atlikti tyrimai tvirtina, kad tikslią, laiku ir objektyvią informaciją apie galimas nepageidaujamas vaisto reakcijas pacientai labai vertina $[5,12,20]$. Ivairių šalių farmacijos profesinių organizacijų atstovai ir mokslininkai ieško būdų, kaip paskatinti farmacijos specialistus kalbèti su pacientais šia jautria tema. Neaptartos ir netiketai pasireiškusios NVR yra viena iš svarbių gydymo nurodymų nesilaikymo priežasčiu [20]. Jungtinèse Amerikos Valstijose atliktas tyrimas patvirtino, jog 76 proc. pacientų tikisi išsamios informacijos apie galimus nepageidaujamus poveikius, net itin retus [21]. Australijoje [22] pacientų apklausa telefonu atskleidè, jog būtent apie nepageidaujamus poveikius užduodama 31 proc. visų klausimų, skirtų sveikatos priežiūros specialistams, o tarp pacientų, nepatenkintų suteikta medicinine informacija, šie klausimai sieke 45 proc. Informacijos ir lūkesčio atitikimas - vienas esminių pasitenkinimo konsultacija sričių [15].

Tyrimas parodè, kad du trečdaliai farmacijos specialistų informaciją suteikè žodžiu, penktadalis informavo žodžiu ir raštu, o tik raštu informacijos beveik neteike. Dešimtadaliui pacientų farmacinė konsultacija nebuvo suteikta (5. pav.). Tiksli, teisinga ir laiku informacija apie vaistus ir sveikatos stiprinimą yra svarbus sveikatos priežiūros ir saugaus vaistų vartojimo komponentas $[3,5,18,20]$. Vaistai - ypatinga prekè. Juos vartojant ne pagal paskirti ar nepaisant tinkamo vaistų vartojimo nuorodų, galima ne tik nepasiekti norimų tikslų (išgyti, stabilizuoti būklę, sumažinti ligos progresavimą ar pagerinti gyvenimo kokybę), bet ir pabloginti esamą paciento sveikatos būklę.

\section{Išvados}

1. Beveik pusé visų vaistinès pacientų apsipirkimo vaistinèje metu įsigyja nereceptinius vaistinius preparatus, skirtus ivvairiems negalavimams ir jų simptomams šalinti. Trečdalis jų pradeda pokalbị su farmacijos specialistu, nurodydami savo sveikatos sutrikimo problemą.

2. Farmacijos specialistai konsultuoja apie racionalu vaistų vartojimą, nors ne visi informaciniai aspektai yra aptariami vienodai dèmesingai. Dažniausiai žodžiu informuoja, kaip reikia vartoti vaistą, rečiau aptaria galimas sąveikas, kontraindikacijas ar nepageidaujamus poveikius. Farmacijos specialistai galètų labiau išnaudoti galimybes užkirsti kelią neracionaliam vaistų vartojimui.

\section{Literatūra}

1. LR Farmacijos įstatymas. X-709. Valstybės žinios, 2006-07-18; 78-3056.

2. LR SAM ministro įsakymas V-494. Dèl geros vaistinių praktikos nuostatų patvirtinimo. 2007 m.birželio 15 d. Valstybès žinios, 2007-06-21; 68-2690.
3.FIP \& WHO. Joint FIP/WHO guidelines on good pharmacy practice: standards for quality of pharmacy services. Geneva: World Health Organization, 2012.

4. Heppler C, Strand LM.Oportunities and responsibilities in pharmaceutical care. Am J hosp pharm. 1990; 47(3): 533-543.

5. World Health Organization and International Pharmaceutical Federation (2006) Developing pharmacy practice A focus on patient care. The Hague, The Netherlands. http://apps.who. int/iris/handle/10665/69399. [žiūrèta 2016 m. lapkričio 10 d.]

6. Saramunee K, Krska J, Mackridge A, Richards J, Suttajit S, Phillips-Howard P. How to enhance public health service utilization in community pharmacy?: General public and health providers' perspectives. Research in Social and Administrative Pharmacy 2014;10(2): 272-284. https://oi.org/10.1016/j.sapharm.2012.05.006

7. Bennadi D. Self-medication: A current challenge. Journal of Basic and Clinical Pharmacy 2014;5(1):19-23.

https://doi.org/10.4103/0976-0105.128253

8. World Health Organization . The Role of the Pharmacist in SelfCare and Self-Medication. The Hague, The Netherlands 1998.

9. AESGP (Association Européenne des Spécialités Pharmaceutiques Grand Public, Association of the European Self-Medication Industry). http://www.aesgp.eu/index.asp. [žiūrèta 2016 m. lapkričio $10 \mathrm{~d}$.].

10. Rutter P. Role of community pharmacists in patients' selfcare and self-medication. Integrated Pharmacy Research and Practice 2015; 4: 57-65.

https://doi.org/10.2147/IPRP.S70403

11. Bell JS, Väänänen M, Ovaskainen H, Närhi U, \& Airaksinen MS. Providing patient care in community pharmacies: practice and research in Finland. Annals of Pharmacotherapy 2007;41(6): 1039-1046.

https://doi.org/10.1345/aph.1H638

12. Schommer JC, Wiederholt JB. The association of prescription status, patient age, patient gender, and patient question asking behavior with the content of pharmacist-patient communication. Pharm Res 1997;14(2):145-151.

https://doi.org/10.1023/A:1012084207399

13. Kaae S, Traulsen JM, Nørgaard LS. Challenges to counseling customers at the pharmacy counter - why do they exist? Res Social Adm Pharm 2012;8(3):253-257.

14. Stevenson FA, Leontowitsch M, Duggan C. Over-the-counter medicines: professional expertise and consumer discourses. Sociol Health Illn. 2008;30(6):913-928. https://doi.org/10.1111/j.1467-9566.2008.01108.x

15. Puspitasari HP, Aslani P, Krass I. How do Australian metropolitan and rural pharmacists counsel consumers with prescriptions? Pharm World Sci 2009;31(3):394-405. https://doi.org/10.1007/s11096-009-9289-9

16. Creswell, J. 2009. Research design: Qualitative, quantitative, and mixed methods approaches. SAGE Publications 2009. 
17. Kardelis K. Mokslinių tyrimų metodologija ir metodai.Kaunas, 2016.

18. Pharmaceutical Group of European Union. PGEU survey on pharmacy education in relation to non-prescription medicines/ Self-care. Brussel, 2012.

19. Wirth, F, Tabone, F, Azzopardi, LM, Gauci, M, Zarb-Adami $\mathrm{M}$, Serracino-Inglott, A. Consumer perception of the community pharmacist and community pharmacy services in Malta. Journal of Pharmaceutical Health Services Research 2010;1(4): 189-194. https://doi.org/10.1111/j.1759-8893.2010.00034.x

20. Vermeire E, Hearnshow H, Van Royen P, Denekens J Patient adherence to treatment: three decades of research. A comprehensive review. J Clin Pharm Ther 2001; 26:331-342. https://doi.org/10.1046/j.1365-2710.2001.00363.x

21. Ziegler DK; Mosier MC, Buenaver M; Okuyemi K. How much information about adverse effects of medication do patients want from physicians? Arch Intern Med 2001; 161: 706-713.

22. Newby DA, Hill SR, Barker BJ. Drug information for consumers: should it be disease or medication specific? Results of a community survey. Aust N Z J Public Health 2001; 25:564-70. https://doi.org/10.1111/j.1467-842X.2001.tb00327.x

\section{THE CONTENT OF COMMUNITY PHARMACY CONSULTATION FOR THE PATIENTS WHO OBTAIN OVER THE COUNTER MEDICATION}

J. Daukšienè, L. Jonaitienė, E. Babonienė

Key words: community pharmacy, consultation, OTC medication, self-medication.

Summary

One of the main roles of pharmacy specialists is to provide pharmacy service: give non-prescription medicines and inform citizens about their health treatment in accordance to governing laws. The use of non-prescription medicines is the part of self-medication, which becomes more popular in a society. However, irrational use of drugs can cause serious health harm. The pharmacy specialists play an important role in the process of ensuring the professional pharmaceutical service is provided. The aim of the study was to assess the information provided by pharmacist to the patients who purchase the OTC medication at Lithuanian community pharmacies. The observation method was chosen. The special form with proposed indicators of encounter consultation was used. In total 4198 consultations were observed and 1738 self-medication consultation were analysed. Results: $41.4 \%$ of pharmacy patients visit the community pharmacy to obtain the OTC medication the main reasons for this are cold $(16.1 \%)$, skin issues $(13.2 \%)$, general pain $(25.6 \%)$, general well-being $(28.7 \%)$ and digestion problems (16,2\%). $38.2 \%$ ask for the advice for this and $37.1 \%$ ask OTC medication by brand name. The informational aspect discussed at encounters is how to use non-prescription medicines (79.6\%), when to use them $(67.1 \%)$, the length of usage $(36.3 \%)$, side effects and contraindications (11\%), possible interactions $(6 \%)$ and none were briefed on alternative treatment methods $(10.9 \%)$.

Conclusions: Self-medication is very common for cold, pain, general wellbeing and digestion problems. People purchase the OTC medication and are provided with information about rational use. The amount of provided information varied among encounters. The most popular aspect was "how to use non-prescription medicines", but rarely inform about side effects, contraindications and possible side effects. The pharmacy professionals could spend some extra time in educating patients regarding the risks of selfmedication.

Correspondence to: jurgita.dauksiene@gmail.com

Gauta 2017-10-19 